\title{
国際学術講演
}

\section{Current Topics and Prospect of International Human Resources Management: Especially Focusing on the Influences of Recent Recession}

\section{はじめに}

経営行動科学学会第3回国際学術講演会は、2009年 1 月 14 日 (水) 16:30 18:00、東京工業大学大岡山キャ ンパス西 $8 \mathrm{E}$ 棟（情報理工学研究科棟）1001会議室で開 催された。

テーマは、昨今の経済危機のもとでの IHRM で、EU の視点から Chris Brewster 先生(University of Reading, UK)に、また、日本の状況をコンサルタントの㧍立場か ら山本紳也先生（プライスウォーターハウスクーパー ス・筑波大学) にご講演頂いた。座長は渡辺真一郎先生 (筑波大学) にお願いし、企画と総合司会を筆者江川が 担当させて頂いた。開催にあたり、顧問の星野靖雄先生 (愛知大学) と会員の永井裕久先生（筑波大学）には格 段のご配慮をいただいた。

講演会では、まず会長の松原敏浩先生（愛知学院大 学）に開会挨拶をいただき、続いて筆者から講師・座長 の先生方を簡単にご紹介させていただいた。

Brewster 先生は、経費削減が向こう数年の主要な焦 点であるならば、財務スペシャリストの力が強まる一方 で人事部門は縮小され、その業務はラインマネジャーに 移されていくと推論された。現時点では推測の域を出な いことが多い中で、Brewster 先生が確信されることの 一つとしてトレーニングの取りやめもしくは縮小をあげ られた。また昨年のご講演テーマでもある海外派遣勤務 者に関しては、明らかに待遇が悪くなり、あらゆる代替 手段によって海外派遣勤務者の数そのものが縮小される と述べられた。

最後に先生は、数年後の景気回復をみこし戦略を熟 慮するか、単にコストに左右されるかを問うならば、い ずれの分野でもコスト主導型になりつつあることに強い 懸念を示されご講演を終えられた。

一方、コンサルタントの拉立場から日本の状況をご 講演下さった山本先生の論調は、Brewster 先生とはト ーンが異なり、とりわけその違いはトレーニングなど人 材開発の継続に関してであった。部品製造の中小企業か ら大手グローバル企業に至るまで、ほとんどの日本企業 ではグローバル経営を牽引できるグローバルマネジャー やリーダーを必要としており、そのための人材開発費は 死守されると述べられた。
江川 緑（東京工業大学・国際学術交流担当理事）

人事部が変わらねばならないという共通認識はある ものの、抎二人の先生方の違いに着目するならば、それ が抢二人の職務の違いによるものか、90年代の日本の経 験によるものか、はたまた人材観や短期・長期といった 時間観への文化の相違によるものか、十分論じ尽くすこ とはできなかったが興味が尽きない内容であった。

座長の渡辺先生の流暢な英語に導かれ、質疑応答で は経済危機下の労働組合、リーダーシップ、メンタルヘ ルスの問題まで多岐にわたる意見交換がなされた。ご講 演の詳細と質疑応答の一部を以下掲載させて頂くのでぜ ひご覧いただきたい。

最後に本講演会の開催にご協力頂いた先生方や参加 者の皆様にお礼申し上げます。

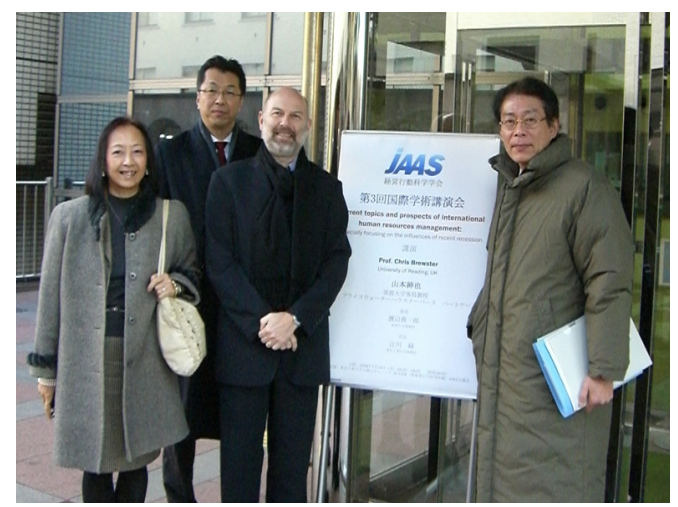

写真 1. 東京工業大学西8号館前にて

右加、渡辺真一郎先生、Chris Brewster 先生、山本紳也先 生、筆者

\section{講演会}

Good afternoon, everyone. My name is Egawa, coordinator of this special lecture. I would like to extend my hearty welcome to all of you here to our university. Thank you so much for attending our lecture, "Current topics and prospect of international human resources management: especially focusing on the influences of recent recession", by JAAS, the Japanese Association of Administrative Science. First, we will have an opening address by our President, President Matsubara of the Japanese Association of Administrative Science. Professor Matsubara, please. 


\section{Opening address by President Matsubara}

Hello, everyone. Upon opening the international scientific lecture by the Japanese Association of Administrative Science, I would like to extend my greeting as a president. First of all, I'm honored to have Professor Chris Brewster from the United Kingdom, University of Reading, and Professor Shinya Yamamoto, University of Tsukuba, as the guest speakers of this program.

We know Professor Brewster as a very famous scholar in international human resources management. Last year, we had a very nice speech from Professor Brewster at Tokyo Institute of Technology. Today, we are very happy to have a good opportunity to listen to a speech by Professor Brewster again. We know Professor Yamamoto as a famous specialist of this field in Japan. Professor Yamamoto is also a Price-WaterhouseCooper Japan partner.

Since last year we had faced a most difficult and serious financial crisis. So, we are eager to look for the solution of this problem. However, unfortunately we have not found one yet. We are looking forward to learning a clue to find a solution for this problem.

Finally, I'd like to thank Professor Egawa of the Tokyo Institute of Technology, who organized this program this year. Thank you very much.

\section{Introduction of the guest speakers and the chair by Professor Egawa}

Thank you very much, Professor Matsubara. Today, as he mentioned, we have wonderful guest speakers, Professor Chris Brewster, welcome back and Professor Shinya Yamamoto. Each of them has 25 minutes to talk, followed by 30 minutes discussion.

Let me first introduce our two guest speakers. Professor Brewster is a well-known professor of international human resources management at the University of Reading. He acquired substantial experience in various organizations, before becoming an academic twenty years ago. I'm sure that most of you here know that he has published over twenty books and more than a hundred articles.

Professor Yamamoto is a Visiting Professor at Tsukuba University and is a partner in charge of PriceWaterhouse-Cooper's human resources services practice in Japan. He has 18 years of experience in human resources management consulting, in service to Japa- nese and foreign companies in Japan, and overseas subsidiaries of Japanese companies. He holds a Bachelor of Science, Engineering, from Keio University in Tokyo, and MBA from the University of Illinois at UrbanaChampagne.

Today's chairperson is Professor Shinichiro Watanabe, Associate Professor of Tsukuba University. He is specialized in organizational behavior, and holds a $\mathrm{PhD}$ from Cornell University.

Now, let's welcome our first lecturer, Professor Brewster, please.

\section{Lecture by Professor Brewster}

Mr. President, ladies and gentlemen, thank you very much. It's a great honor to be back here. It's a particular honor being here the second time, because that seems to imply that the first time wasn't so bad that you didn't want to invite me back. So, I am very honored to be back here with you.

This is the first time really that I've tried to do a presentation that is not based on my research. I'm going to tell you something about the trends that have been happening in human resource management in Europe. And then what I'm going to speculate about how organization in Europe will cope with the current economic circumstances outlined by the president. As he said, we don't have any solutions; we're still in the middle of this, and therefore, in research terms, it's not possible for me to know exactly what companies are doing right now. So, in that respect, when we get to the bits about what's going to be happening, I shall be guessing. I shall be speculating. But first of all, I want to tell you something about the research that we've done. So, what I'll do is, I'll tell you something about the research base. I haven't got the articles and Professor Watanabe suggested that it might be useful to send him a copy of the articles with the statistics in it, and I'm sure we can make arrangements for those of you who want to see the statistics. The paper is not yet published. Indeed, we haven't finished writing it yet, but the statistics are there, anyway, with some first attempt at the theory that goes around them. So, I'll send that paper to Professor Watanabe as soon as I can, and hopefully those of you who are interested in that can see what's in there. I haven't presented the statistics here, because I wanted to concentrate on the substan- 
tive findings.

So, I will spend quite a bit of time looking at the trends, what we found going on across Europe, and then I will guess what may be happening at the moment and in the future. What we'd like to do, I think, is to then compare what's going on in Europe with what's going on in Japan, and that's what Professor Yamamoto will be covering. And then after that hopefully we can have a discussion amongst ourselves as to the differences between the two, and whether our speculations are accurate...or what we feel about things.

So let's start with the research base. We have a very large survey now. It covers, currently, 24 countries in Europe, and a lot of other countries including Japan and the United States and Australia and South Africa, but I shall be concentrating on what's been going on in Europe.

We repeat this survey every three years. Therefore, over the last 15 years, we can tell what's been happening to human resource management. I can't tell you how many responses we get because obviously it varies each time we do it, and it varies a little bit depending on how many countries we can get to complete the questionnaire. But there are literally thousands. The research we are talking about is based on about 40,000 responses. So, we are relatively confident that this is an accurate picture of what's been going on.

The questionnaire goes to the most senior human resource management specialist in the company and it's factual as far as we can manage. That is, we ask for numbers and yes/no answers wherever possible. My friends in the consultancy business tell me that it's a very boring questionnaire, because we don't ask about future developments, exciting trends and so on. We just ask what they're actually doing and what's going on in their organizations.

And, I need to say, it's a representative survey; it's not a panel survey. So, we haven't followed the same companies through for 15 years, if such a thing were possible anyway. What we have done is try to make sure that the sample represents the nature of the business going on in that country each time that we conduct the survey. I think that's important. For example, when we started preparing the survey back at the beginning about 15 years ago, IT companies were quite a small proportion of the economy. Now, they're a much bigger one. If we'd have had the same companies, it would have become unrepresentative of what's actually going on.

We've been looking at this issue of convergencewhether these countries are getting more and more alike in the way that they are managing their people. Convergence would mean, that the countries are actually getting closer together in the way that they manage their people over a period of time. So, it may be that one country's increasing something, but another country's decreasing it, but they're actually getting closer together. Or it may be that one country is increasing things and another country is increasing things even faster, but because they started off lower, they're getter closer together. So, we look to see whether countries are getting closer together in the way that they're managing their workforce.

And the answers are very easy for us to work out, because they are not - there is absolutely no evidence that countries are getting closer together. In fact, they're staying just as far apart as they were at the beginning. Over 15 years, they haven't moved together at all, either in the way they shape their human resource departments - the configuration of the human resource department - or in the various practices of recruitment, training and so on. The countries started quite differently in those respects, and they've ended up still very different in those respects.

People often talk about convergence though when they mean trends. You hear people say, "There's an increase in use of flexible working practices, nonstandard working patterns, in all countries, so therefore, they must be converging." Or they say, "There's a decrease in the membership of trade unions, that's happening in nearly all the countries, so that must mean the countries are converging."

But, of course, it only takes a moment's thought to see that two countries could be doing the same thing but they end up over a long time period just as far apart as they were when they started. Common trends don't mean we're all getting more the same. They just mean there are common trends. These are the trends that we found. And I think I'll just spend a couple of minutes to clarify these, because I'm then going to suggest what might be happening now. 
So over the past 15 years we've found an increasing strategic potential of the human resource management department, which means more and more human resource management specialists represented on the main board or main decision-making body of the company. It means those people at that level are more and more involved in corporate strategy at an early stage. So, things that have got nothing to do with human resource management immediately - like changing a product line, or stopping a product or opening up business in a new country —of course will have implications for the people that an organization employs, and organizations are trying to take account of those things now before they make those decisions.

There is more and more of human resource management that should have been assigned to line managers - they're the people closest to the people being employed in the organization, but increasingly more and more of that is being done by the human resource management department. They're taking a bigger and bigger role. And the human resource management department is becoming more professional. More people are trained in human resource management, or in business, or in law, or in psychology - useful degrees in the process of human resource management.

In Europe, traditionally human resource management has been staffed by people who've done arts degrees, or something that perhaps was not terribly relevant to their work. So, we're getting better degrees, more relevant degrees, and they're doing further training. So, that seems to be happening in most of the countries, most of the time we looked at it.

There are also changes in human resource management practices. For example, in most of the countries, most of the time, organizations are getting smarter about the way that they try to look for people, and the way that they select the people they can attract to apply for jobs. We know that there are smart ways of looking for people, getting into the universities early, using Web technologies, and there are smart ways of selecting people. We know, for example, that interviews is a very bad way to select people. It doesn't generally give you a very good picture of whether people are going to be successful in the job. Things like aptitude and skill testing, psychometric testing, assessment centers and so on seem to be used more and more. So, across most of these countries, most of the time, employee resourcing is getting more sophisticated. Employee relations, dealing with the staff's contracts of employment, is increasingly being done outside the trade union context. So there are more and more individual negotiations with individual people rather than negotiations with the trade union.

There is more and more information going to employees through all sort of different channels. Through the trade unions, indeed, through consultative committees, and also through e-mail, through newsletters, through management meetings and so on... And, more information coming from employees into the management team. It's, after all, employees who make the products, employees who provide the services, employees who meet with the customers, and they are the ones who know what's needed in terms of new policies.

And there is more and more use of contingent compensation systems. That means people don't know what they're going to be paid at the beginning of the year, because at least some part of it depends on performance in some way. Now, different countries in Europe do that differently. So, some countries, like France, link their contingent compensation systems to the company's profits. It's a kind of profit-sharing basis. Some countries, like the Scandinavian countries, prefer to have group bonuses, because they say, "Teamwork is very important in our organization." Some countries, like the UK, prefer to have individual performance related pay systems. But there has been an increase of these contingent compensation systems right across Europe.

We didn't find any common trends in the staff ratio-the size of the HRM department. Most of the HRM people we spoke to told us that the HRM departments were getting smaller and being asked to do more work. We assessed that over 15 years. The article's been published in the Journal of International Business Studies, so we're pretty sure about that. There is no trend of that kind apparent. The size of the HRM function now, in percentage terms, is almost exactly the same as it was 15 years ago. And, rather depressingly, no trend in employer development. We didn't see more training going on. We didn't see any up-skilling of the workforce. Some years it went up; 
some years it went down. Some countries it went up; some countries it went down. So, no trend in that direction either.

All of this, of course, is backward looking. This is proven material about what's going on looking back over the trends of the last 15 years. And what we see is that overall, in most cases, human resource management is becoming more and more sophisticated. Increasingly, human resource management is getting to look like the textbooks, and the experts, and the consultants and the gurus tell us it should be looking like. They tell us it should be more strategic, more professional, that there should be these more sophisticated practices. And it appears as if that is indeed, what is happening across Europe in the last 15 years.

But the question I was asked to address here is "What's going to happen, given the economic crisis?" Now the economic crisis is not the same in all the countries of Europe, for example. It's much worse in my country, the United Kingdom, because we have a very large finance sector. Twenty percent of the total employment in Britain was, up until a few months ago anyway, in the financial sector. Now there's been lots of redundancies and so on, so that figure may be out of date. But that figure was easily well above the figure of the finance sector in most other European countries. Some European countries have been much more cautious in their banking and their lending than other countries, and we might guess that the downturn will hit them less badly than the others. But the reality is that there is no country in Europe that is not going to be affected by this downturn. It's going to be a problem for everybody.

So, here are my guesses about what that's going to mean to the developments in human resource management. I stress again that this is speculation; we're just guessing about what's going to happen. So, I think that the increased power and influence of the human resource management department that we've seen over the last 15 years is likely to be going down. The reasons for that are that the increased strategic role of human resource management people was very much a function of the fact that the key problem facing businesses was a shortage of talent. We couldn't get the right number of people that we needed in a very tight labor market. Therefore, the people who could attract that talent became very important people. Now, attracting talent is not the problem. The problem is getting rid of talent. So that's fairly straightforward.

My guess is that ironically and strangely, the people who are going to gain out of the current crisis are going to be the financial specialists within the organization. Although arguably they're the people who got us into this crisis, if cost-cutting becomes the key focus of organizations over the next couple of years, then it's likely that the people who know about those costs- the financial specialists - are going to be the people who gain power. So, I guess that what's going to happen is that the HRM departments will lose power and the finance departments will gain power.

I guess that more human resource management responsibility will be allocated to line managers - that they will be asked to take the decisions about who goes; that they will be asked to decide who, if anybody, gets any training; and so on and so forth-because the idea will be to link anything that happens to the requirement within the business. My guess is that, where there is human resource professionalization, it will continue, and that there will be an increased pressure, trying to get people to think very carefully about this, because, although I've said that finance people are likely to gain power at the expense of the human resource management people, still we know that for nearly all organizations, the largest single element of their operating cost is the cost of the people. So, if they're going to do something seriously about the cost of the people, their going to need fairly professional human resource management people who can offer them some options.

In terms of HRM practices, my guess is that the sophistication of recruitment policies will reduce because recruitment is just not an issue for most organizations. There's probably going to be very little recruitment. It's something that happened, as I understand it, in Japan, 15 years ago and Japan got into a lot of problems. The recovery took a lot longer because the right people were not coming into organizations. My guess is that in Europe we will repeat that mistake. Hopefully, in Japan, you've learned from that mistake and will get it right this time. But my guess is that there will be very little recruitment, and what there is will be done on a much less sophisticated basis, because those sophisticated forms of recruitment cost a lot more money 
than just interviewing somebody.

My guess is that the role of the trade unions will increase, like the finance specialists they will gain from the crisis, because when you've got a situation of redundancies and you've got problems of cost-saving, it's going to be important to keep the unions "on-side" as we say - to keep the unions with you. My guess, therefore, is that the unions will become more powerful again.

I don't know what's going to happen to information to employees. My guess is that some parts of it probably will continue to increase. So, information about what the organization is trying to do, and the strategy and so on, will continue to be given out to employees. But they'll probably get much less information about the financial results of the organization because the organization won't want to frighten people, and they'll want to keep that information relatively quiet. It's uncertain-my guess is there won't be much of an increase certainly, at least.

And on contingent compensation systems, I doubt that there'll be very much change as a result of the crisis. Now, so many organizations use these that it's likely to be seen as not the time to be trying to make major changes to payment systems. We just carry on with what we've got. Unlike the past 15 years, my guess is that the staff ratios will do two things. The size of the HRM departments will probably get bigger in the next few months because getting rid of people requires experts to do that. But once those job cuts have been made, then the next place for job cuts will be the human resource management department itself. It's an overhead department not contributing directly to profits, and therefore, it will be under, I guess, ever more pressure.

And one thing I'm very confident about is that training will be cut, and training will reduce. It happens in every downturn in every economic cycle. Training is something that's easy to cut without having an immediate effect on the profitability of the organization. And I guess, therefore, that that's going to happen in the future. Now, whether these changes are smart, whether they're the right thing to be doing, I think, is another issue. I'm just guessing about what will be happening.

I just wanted to add in my own area of specialism, international human resource management, linking to what I discussed last year, and to talk about some of the implications there. My guess is that we will see a reduction of internationalization. Organizations won't be expanding into new countries. They won't be developing their operations in subsidiaries. In most downturns, subsidiaries get cut harder than headquarters country operations-largely for political reasons, but simply because it's easier to cut things out at the edges of the organization rather than near the center. And I guess that will continue. One exception might be where organizations are putting some of their production or some of their service capability into cheap labor countries. And if you're trying to cut costs then continuing to do that makes a lot of sense.

I think there will be tougher negotiations with expatriates. I think they won't be given the wonderful packages they've been given up to now. They will be expected to manage with a little bit less. Some will be asked to go and live in a foreign country on local conditions - that's relatively straightforward to do. There's about 30 countries in Europe where you can say to people, "Well, living standards are good, and it's a nice place to live anyway. We're not going to pay you a lot of extra money to go there." There will be less use of consultants. They've done very well out of the boom years. I think they will suffer in the recession years, not just here, but in a lot of other ways.

Companies will try to find ways to conduct their international operations without expatriating people, because expatriates are very expensive people. They will therefore try to find other ways: short-term assignments - three months or six months, where they can send people who don't have to take their families with them, for example. That's saving a lot of money. There will be more regional transfers of people, people moving just within Europe, or just within the Asia-Pacific region, whatever... There will be more people just traveling backwards and forwards, almost as commuters to check on countries. More frequent flying, more self-initiated expatriations. If we need to employ somebody in America, then maybe we can find a Japanese person, or in our case a British person, who's gone to America anyway and employ them over there. They'll give us some of the advantages of having an expatriate there - the language capabilities, the understanding of how we do business at home, but without the costs of 
us actually sending them there themselves. And there will be more and more reliance on virtual teams and virtual mechanisms: e-mail, teleconferencing, tele-visual conferencing and so on. There will be less support for expatriates. They will be given less backup from people at headquarter than they've had done up to now.

And the question here-as everywhere else, I think-is, is everything going to be carefully thought out strategically, with a view to deciding what happens in three or four year's time when things are going well again, or is it going to be just driven by costs? My fear is that it will increasingly be driven by costs. Thank you very much.

\section{Lecture by Professor Shinya Yamamoto}

Well, first of all, thank you very much for giving me this opportunity speaking here. As I was introduced, I am a full-time management consultant for PricewaterhouseCoopers, and a part time professor at the Business School of University of Tsukuba, Tokyo Campus. So, what I'll talk about today is based on my view. If I use the word Professor Brewster used, my presentation today is 100 percent based on speculation or my personal point of view, not based on research. Please understand, it's not really my subjective view, but what I hear from the discussion with HR directors around, and also discussion from other $\mathrm{PwC}$ consultants around the world.

As I was given this topic, I'll talk about what I see at this recession, or what's expected at this stage, and some comparison to what we have already experienced in the 1990's, when the so-called "bubble economy" was burst.

There are two phases or aspects that have to be considered. The first is the short term solution to overcome the current circumstances, the second is the long term solution being ready when the economy comes back. As you understand, "It's easy to say, and it's difficult to do," is probably what every HR director has in their mind at the moment. In order to overcome this sudden situation, you have to, of course, do something this year. But at the same time, you have to be ready for the recovery stage after the bottom of the economy, since HR management is not a one-time solution.

What I see in the market, or should I say, what I'm starting to see in the market, as I've been talking to the HR directors, the cost reduction is, of course, the first priority. Even after the bubble economy burst in the 1990's, the HR cost has been the last area to touch upon for the cost reduction. It's probably so in different countries too, but probably especially so here in Japan. As you understand, it's not easy to make redundancy in this country. So, it has been... Some people said, "We have already done all the cost cutting, cost reductionevery area we can think of-but HR." So, it's the last area you have to touch on.

Cutting the number of people is something companies start doing - this is probably something you read from newspapers every day these days - but the companies try not to stop recruitment. I'll talk about this a little later, but they are trying to keep the new graduate recruitment. That's what I hear-I don't know if they can really keep it so. That's what I hear a lot from HR directors these days. In early 1990's, many companies stopped recruitment including new graduates. And now they face a lack of middle-level engineers and middle managements after ten to fifteen years. So, people are trying to avoid the same situation, they try to keep the newly graduate recruitment, but not the expensive midway recruitment.

A hot topic in this country, as you see, is reducing temporary staff costs and overtime costs, by carefully managing the work productivity. Of course, you can't do something illegal, but the reduction of the temporary staff or the special contract employees has been hotly discussed and will continue to be discussed.

And, of course...the bonus and salary adjustment. What I mean by, "The strict and severe performance appraisal and its reflection to HR," means mostly pay control. We had introduced a performance-based type of appraisal and pay system in the 1990's, but the practice itself-how you practice that system - was kind of loose. Trying to strengthen this and pay only for the people you really need to pay means someone really performed, and try to reduce the pay for those people who are not really performing may be more and more demanded. That will probably be the trend.

Another trend may be the work-sharing issue. This just came out as a topic a few days ago, as you saw from the news. We have been discussing, why not...people are talking about a work-sharing plan. But, in order to recover from probably a few years of reces- 
sion to come, I would believe- this is really a speculative area-but more of work-sharing discussion comes into the market, even though there are some legal issues has to go through.

And then lastly, redundancy. This is something, how shall I say it, that hasn't come into the discussion and hasn't become news yet. But, it is really my feeling that the full-time employee redundancy issue will be on table soon.... This is something to be finished up by this coming spring for the next fiscal year. A pure redundancy discussion for the full-time employees will probably come onto the table.

So, that was the cost-reduction issue. But, at the same time, as I said, you have to keep continuous development for the next era-the business recovery stage. And this is contrast what Professor Brewster said. I don't know how much they really can keep it, but HR directors say, they would love to, or they would be keen to keep the budget for HR development, a learning and education budget, as much as possible, so that they can really recover when the economy comes back.

And the specific issue for Japanese companies is - to develop managers and leaders who can lead global businesses. This has been really a big issue. From small components manufacturing to the huge globally known companies anyone can name, almost all Japanese companies are really struggling with global management issues. In the 1970s and 80s, we invested outside of Japan a lot, but that wasn't really strategic globalization, but for financial, production or sales reasons. But now it's really a strategic expansion phase...to win a global market. And companies are looking for managers who can strategically manage these real global businesses.

As I said, about a recruitment, they don't want to make the same mistake which they made in the 1990s. As they have a plan for growth in ten years, they would love to keep new graduate recruitment. Of course the plan may be reviewed or will be reviewed, and they may have to reduce the scale of recruitment, but they don't want to stop. That's what I hear.

Let's go back to 1990s. What happened - this is just a review. The bubble economy, as I wrote here, especially for Japanese , it was completely a different economic situation and including the HR system, it's not only HR-procurement system, production system, logistics system - all these business models were reviewed and re-engineered in 1990s, while we were still making some money outside of Japan. The economic down trend was only a domestic issue.

But this time, we don't have revenue from outside of Japan. We have to do something this year. What I'm trying to say is like, many people ask me as a consultant, "You have a chance again, because of this recession, a lot of companies trying to reform their HR system, so you have bigger chance of doing consultancy, right?" The answer is NO. It's completely a different situation from 1990s. What we did in 1990s was, trying to get away from seniority system to more of performance-based pay HR system, and it took five years to adjust the system and the pay level, aligning to a Japanese legal requirement. The first year, you don't decrease the pay, or you don't cut people. You probably needed a higher budget or higher HR cost to adjust the system for the first and the second years, because your cannot simply decrease the pay, but you have to increase the pay for some of those doing better performance.

So, that is what we had done in 1990s, adjusting the pay level in five years. But this time, you don't have that time. The management's talking about this year, not talking about five years ahead. So, it's a completely different situation.

As discussed, in the 1990's, we stopped the recruitment, or reduced quite significantly. And also, the companies dismissed many people with voluntary retirement program. That time, there were a lot of people so-called "bucho"or "fuku bucho", which is just a title and doing not much work but paid a lot. Companies reduced a lot of those people, and strengthened organizations in the 1990s. And we don't have that bubble or extra people any more, not this time.

And then, this is something I'm worried about..."Reduce headquarters management staff, including HR staffs." This happened in 1990s. And I personally see the bad outcome from this movement. In Japan, people often joke about HRM, saying that HRM is not "human resource management", but "human relationship management" in Japan. I do not know if this is just a joke. Running under the Japanese way of management - especially with the lifetime employment 
practice, working together for 30 years or 40 years, and when HR was not really sophisticated and scientific, human relationship management had been a key for management. What I'm trying to say is, HR people, the HR department in Japanese companies knew their employees and business very well, because of their strong people relationship. It was not by video screens, but by knowing each other, talking to each other. And that was pretty much the heart of HRM in Japan. I'm not saying this is good or bad, but without fully changing the management system, the reduction in the size of HR staffs simply damaged that information flow and relationship between the business site and HR. Now HR has very little information about the business and the people, and is struggling to be a productive business partner. I think this must also be...maybe a small part, but... mistake we have made in the 1990s.

I would also like to discuss a little about ushinawareta jyuunen, the "lost decade". This is something we've talked about a lot after the bubble economy. This was a term used in finance, but I don't think this was really finance. It was an HR issue to me. We have lost the human capital investment of the ten years after the babble economy burst. If it's just money, we can recover, but human resource development we cannot recover. I'm in my late 40s, and when the bubble economy was burst I was 30, and we had a 15 year recession since. We have faced two percent GDP growth, three percent inflation in 15 years, and no expansion, or no growth of the company size in fifteen years. Our generation, from age of 30 to 45 , within the same organization, lifetime employment, faced no expansion of responsibility, doing the same thing for 15 years - we've lost a lot of human capital, human resource development. That's a big loss we have seen in the past 10-15 years. This time, this year, it can not be 15 years. We have to recover in a year or two anyway. Otherwise we will have a real problem. So, it's a different situation.

As we have discussed, the situation is different in 1990s and today. The pressure on cost-reduction is really the short-term issue-you really have to think what you can do this year. Immediate cost reduction is required. But, as I said, we have done several reengineering and re-structuring in the 1990s and not much left we can cut costs. That's a reason we are sort of stronger than other countries, today. People out- side of Japan are looking at Japan as healthier than the other countries at the moment. We have little to probably reduce the cost, and that's a difficulty we may face.

And then, as I said, human resource cost is probably the last one we have to touch on. And what we will probably see this year is - again, the HR cost reduction, using every methodology you can think of, being as low as you can think of. It's a survival game for the company, as you see the big deficit figures from companies that never had a deficit. It is serious. HR will face strong pressure to cut cost anyway you can.

At the same time, HR may be asked to be more strategic. A question is "are people really making money? Does HR understand that?" A "return on investment in people" type of idea may be demanded. HR management has to be more scientific, managed by numbers. That type of trend is becoming hot topic in the US, but not in Japan. However, because of this current situation, people may start talking about this.

And business effectiveness is demanded. As I said, HR has to understand the business more. It's a classic discussion for years. Professor Dave Ulrich, of Michigan, was also focusing on business partner role of $\mathrm{HR}$. When he came to the PwC conference last spring, from his strategic HR model, he didn't talk about HR being a change agent, but he focused on HR being a business partner. And to be a business partner, you have to understand business - you mustn't have too little knowledge of business. That's really the issue, and to be a stronger business partner is something HR may be strongly asked for.

Being global is another issue for HR. Strategic global business development is requiring strategic global HR management, but current HR is not answering. As discussed, here in Japan, we're talking about the recession, how bad our economy is, how bad our company is, how difficult this year is. But if you go out of Japan and talk to British people or American people or others, they're talking about how Japan's still healthier than them. I hear that, in order to recover from the current circumstances, the situation, it's really the Japanese money that has to take a role outside of Japan, which means mergers and acquisitions by Japanese companies outside of Japan is demanded. That's what the global economy is looking for, and because of the strong 
Japanese yen, this is a chance for Japanese companies too.

So, in order to do this, it's really global management that is required - the key issue. I mean, buying is a money issue, but can you really manage after you buy a non-Japanese company is an HR management issue we face. And last concern I have-if you look at the figures in the past, this year, this spring's shunto, the discussion with the labor union, it's a very unique and difficult situation we face. This is the year we have a positive inflation with a big loss in corporate financial result. This is something we see for the first time in thirty years. And in the past since bubble economy, we didn't really have inflation for many, many years. But this year, we have annual inflation positive, and the union, of course, has to ask for their salary increase, but I don't know how companies can answer with the huge loss they're facing.

That's all I prepared for today. This was not really an academic speech or anything from a research, but this is what I see recently as a consultant in the market. Thank you very much.

\section{Partial introduction of $Q$ \& A chaired by Pro- fessor Watanabe}

Professor Watanabe: Thank you very much Professor Brewster and Professor Yamamoto. And the talks was very interesting. Professor Brewster's talk was based on his own research. He did not show us any statistics, but I know that the content of his talk was based on his research.

And Professor Yamamoto's talk was based on his research consulting work. This is very powerful, and we cannot get that kind of information from just reading past research. That is very valuable.

Chris, this may be surprising to you, but in Japan, age discrimination is very strong. It exists, and my major is in organizational behavior, not in human resources management, so as far as I know from my own research area, the correlation between age and job performance is believed to be high. So, there is a myth that older workers are not productive. But the myth is broken now. The recent research is looking at the relationship between those two variables according to different jobs or job types.

The correlation becomes less and less strong in ma- nual labor, but in salespeople the correlation is still very strong - it's even rising. So, the performance in some jobs is dependent on experience, so we have to think about how we should treat older people from now on. So, Professor Yamamoto said we have to continue to hire new recruits, but at the same time we have to effectively think about how we can use older workers in the companies.

Professor Ohtsu: Professor Brewster, I'm just curious to know what the European labor movements are doing, I mean in order to survive. Companies are trying to cut costs, as you said, by means of reducing the workforce and containing wage increases - meaning that workers are getting the short end of the stick. Now, the labor movements are supposed to represent the interests of those workers, and I'm just curious. How do you see things for example, at the macro-level, if not at the shop-floor level?

Professor Brewster: That's a very good question, of course. I think the answer depends on which particular part of Europe you're looking, because, as you already know, the labor movement performs different functions in different countries. So, in the Nordic countriesFinland, Sweden, Norway and so on-the labor movement is very strong. Membership is 80 or 90 percent of the total working population, but it's also very cooperative. Their view is that it's part of their business to make their companies as rich and successful as they can, because that way the members will stay in jobs and they will be able to get pay increases.

In France and Italy, the trade union takes the view that everything the employers have is something that the employees don't have. And therefore, their job is to fight the companies to get as much as they possibly can. In Britain and Germany, probably our labor movements are kind of somewhere in between those positions. We're not quite sure. We used to be fighting the employers - we're trying to become more like the Swedes and the Finns, but we're not quite sure where we are.

I think that, just to pick up on something Professor Yamamoto said, in Britain at the moment, the situation is that our companies are losing money, so they're not in a position to offer pay increases, but our inflation rate is at four percent. So, if there are no increases, then people's living standards come down by four percent. 
That's a pretty tough position to be in. My guess is that the labor movement will be much more active over the next couple of years, so that we will see more disputes, more strikes, more problems for managers in handling the trade unions. But that ultimately, whatever they do, they will fail, because I think the economic reality is that wages and wage costs will have to be reduced.

One of the things that the European labor movement is trying to encourage is - they used to talk about "gain sharing", now we're talking about "pain sharing"saying to people, instead of losing, having 20 percent of the workforce dismissed, why don't we get everybody to only work four days a week, because that way you'll get a 20 percent reduction in costs in production, but it will be shared by everybody and we don't end up with 20 percent of the workforce totally without a job.

So, I think the labor movement is likely to push in that direction, in terms of things like "pain sharing" and in terms of coming up with rather smarter ideas about how costs can be reduced, other than just getting rid of people. But I can’t see them having any real successes in the next couple of years.

Professor Watanabe: We are in economic recession in Japan, and in Europe. I'm from OB and we'd like to discuss what we can do-what studies we can do- to overcome this very sad situation, global sad situation. For example, from my area, one possible study is about leadership. Probably about who was successful when the economy was in a stable position? But they may not continue to be successful in this recession. So, what leader traits will be a key to the success when the economy is very hard like this? Maybe such studies will be possible, for example, courageous leadership. Can leader say, "Okay, this is our decision, we've just reached. Let's do it! Let's go ahead. I take all the responsibility. Then, you do it." And this kind of leadership, maybe called "courageous leadership" has not been studied yet. But this kind of study may be possible in the future...and any other opinion from your own area? Egawa-sensei-how about how to maintain mental health in this period of recession? That's a very important topic to pursue, because mentally healthy people can be productive. That's what past research shows.

Professor Egawa: Yes, it's very important issue but also very difficult issue to solve by individuals, I mean by each employee.

Professor Watanabe: Oh, that's right.

Professor Egawa: Rather, a social or organizational supportive environment is essential to reduce the social stress and maintain mental health. In this sense, to encourage work sharing and work life balance will be one of the useful options to create healthy organizations. My understanding is that even at this most difficult time, still some companies including small ones are attempting to overcome the situation with work sharing without redundancy. At these companies, employees can keep their mental health without fear or anxiety. At the same time, they can balance their work and life which will surely promote their mental health and performance. It would be worth studying these companies to understand what makes them different.

Professor Watanabe: Yes, thank you very much. Thank you very much everyone for participating in this session. So, we have to call it a day. Thank you very much.

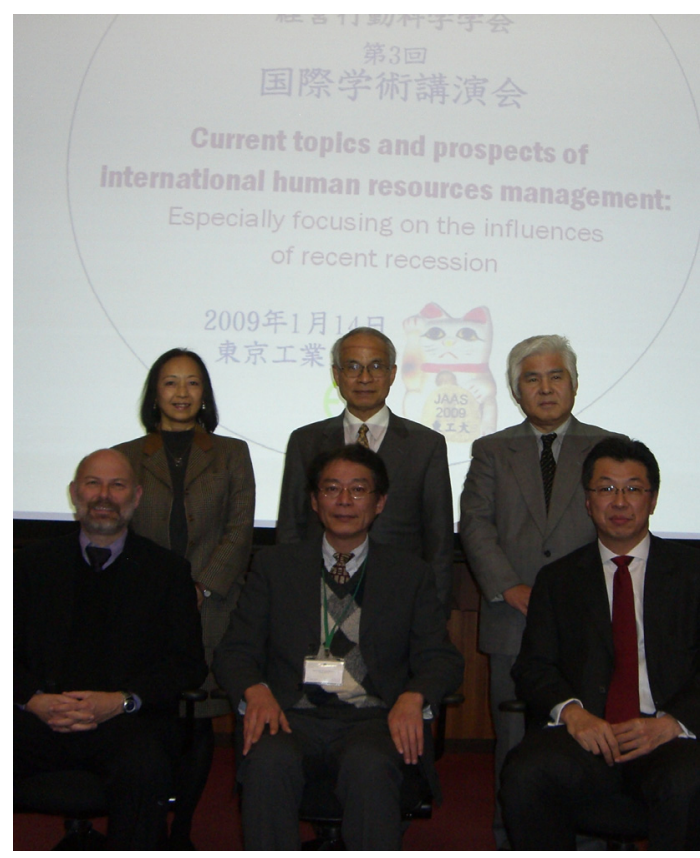

写真 2. 講演会後の会場で

前列左加 Chris Brewster 先生、渡辺真一郎先生、山本紳也先生 後列左加筆者、松原敏浩先生 (会長)、大津誠先生（研究担当 理事) 
